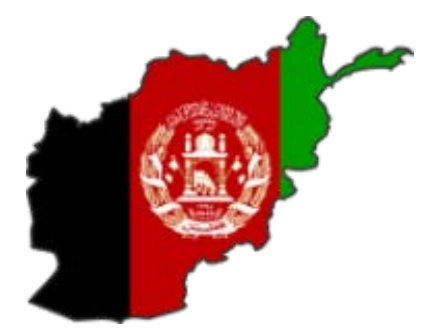

Independent Joint Anti-Corruption Monitoring and Evaluation Committee

\title{
Vulnerability to Corruption Assessment on Wasaeq Registration
}

(VCA Unit)

Kabul, Afghanistan

March 2015 


\section{ABBREVIATIONS/ACRONYMS}

$\begin{array}{ll}\text { DPC } & \text { District Pricing Committee } \\ \text { DWR } & \text { Directorate of Wasaeq Registration } \\ \text { GDWR } & \text { General Directorate of Wasaeq Registration } \\ \text { JPC } & \text { Joint Pricing Commission } \\ \text { MEC } & \text { Independent Joint Anti-Corruption Monitoring and Evaluation } \\ & \text { Committee } \\ \text { MoF } & \text { Ministry of Finance } \\ \text { MoJ } & \text { Ministry of Justice } \\ \text { RD-MoF } & \text { Revenue Department in Ministry of Finance } \\ \text { SC } & \text { Supreme Court } \\ \text { VCA } & \text { Vulnerability to Corruption Assessment }\end{array}$




\section{SUMMARY}

This Vulnerability to Corruption Assessment (VCA) examines the process of Wasaeq (certified or notarized documents) registration. The VCA team identified a range of vulnerabilities, many of which are due to a failure to observe laws and regulations, poor inter-institutional coordination among government stakeholders, and significant human-resource and technical-capacity deficiencies. These deficiencies combined with organizational structure issues, lengthy and overly complicated bureaucratic procedures, and overlapping responsibilities within different entities, all of which combine to create an environment conducive to a range of corruption vulnerabilities.

\section{INTRODUCTION}

While there is no direct English translation for the word "Wasaeq," the word encompasses a range of notarized and certified documents, including property registration and marriage certificates. In all, the General Directorate of Wasaeq Registration (GDWR) issues approximately 45 different types of certificates and documents. The GDWR is contained within the organizational structure of the Supreme Court (SC) with specific mandates to issue certifications and manage record-keeping databases.

This is the second Independent Joint Anti-Corruption Monitoring and Evaluation Committee (MEC) VCA targeted at the justice sector in Afghanistan. While the VCA Team made it clear to all stakeholders that our activities would only focus on procedural and organizational issues, the SC failed to provide the level of cooperation required to obtain a comprehensive picture of Wasaeq procedures and corruption vulnerabilities. While several GDWR staff members were very receptive to the VCA Team's work, other relevant departments within the SC structure, particularly the Makhzan (Archives) Department, failed to cooperate.

As with the VCA Team's work on corruption case tracking, the SC justified its lack of cooperation by citing its "independence," implying that our work constituted "interference."

\section{VCA COLLECTION METHODOLOGY}

The data for this VCA was collected through consultation meetings, focus-group discussions, and observations of Wasaeq registration processes. The VCA Team consulted a wide-range of stakeholders, including:

- The GDWR of the SC

- District 4 and 10, The General Directorate of Properties, The Audit and Revenue Department of Kabul Municipality

- Appeal Court, Parwan Province

- The General Directorate of Governmental Affairs/Issues, Ministry of Justice (MoJ)

- Joint Pricing Commission (JPC), consisting of MoJ, Ministry of Finance (MoF) and Kabul Municipality representatives

- District Pricing Committee (DPC)

- The General Directorate of Revenue, MoF

- HARAKAT (an NGO)

- Afghanistan Land Consulting Organization 
- Real Estate and Property Dealers

- Citizens seeking services from the Wasaeq Department

\section{LEGAL/REGULATORY FRAMEWORK ISSUES}

The legal framework of Wasaeq includes the Law on the Structure (Tashkil) and Competencies of Courts, provisions of Afghan civil law, as well as various rules, regulations, and guidelines issued by the SC. As a general observation, many of the laws and regulations relevant to the GDWR appear to be frequently ignored. This is consistent with the VCA Team's findings concerning organizational structure and human resource issues discussed in Section 5, which are also characterized by a significant failure of government entities, including those within the SC structure, to observe the GWDR's mandate.

\subsection{LAW ON THE STRUCTURE AND COMPETENCIES OF THE COURTS (2013)}

According to Article 74, Paragraph 1 of the Law on the Structure and Competencies of Courts:

A Document and Wasaeq Registration Directorate will be established within the judicial area of each Appeal Court.

Based on this Article, the SC is required to establish Wasaeq Directorates at the provincial level. In practice however, there are no Wasaeq Directorates in most of the provinces and many of the responsibilities have been delegated to civil court judges. According to interviewees, this not only causes delays in issuing documents, but also slows down the process of adjudicating civil cases. In addition, the lack of GDWR line directorates compromises information sharing and coordination between the GWDR at the central level and in the provinces. Interviewees stated that a significant amount of documents issued at the provincial level by civil court authorities are not sent to the GDWR in Kabul.

\subsection{Property Tax Assessment Regulations}

The outdated regulations and guidelines used by the DPCs for property tax assessments constitute yet another challenge in the Wasaeq legal framework. The current regulation provides guidelines for assessing property values for tax purposes based on a number of defined criteria, including the physical state of the property, square footage, and location. Interviewees stated that the guidelines should be updated, as they lead to the undervaluation of properties, and therefore a significant reduction in potential government revenue.

However, based on a decree by former President Karzai, the General Directorate of Revenue Department in the MoF established the JPC, consisting of representatives from the MoF, the MoJ, and Kabul Municipality. The JPC is tasked with conducting assessments based on a property's current "market" value. Interviewees noted that the JPC and its activities are technically illegal and that the assessments are not based on true market value, making determinations inconsistent and, because of vaguely defined organizational parameters, subjected to limited accountability. This makes the property-assessment process highly vulnerable to corruption. Some interviewees familiar with the JPC stated that assessments often significantly exceed the true market value unless bribes are paid to assessors or other influential officials. Furthermore, interviewees noted their belief that the 
JPC was established due to the "personal interests and affiliations" of some revenue-zone managers, and not because of sound public-policy goals.

While the JPC issue is limited to land and property registration, it is indicative of broader institutional integrity issues associated with the Wasaeq system and the SC structure under which it operates.

\subsection{LACK OF IMPLEMENTATION OF SUPREME COURT RESOLUTIONS}

SC Resolution 387, which was issued on February 12, 2011, eliminated the use of brokers in the Wasaeq property-registration process. Due to the lengthy and complicated procedures for registering property, people are sometimes forced to rely on brokers to complete the process. It is believed that brokers often work in collusion with government personnel, and Resolution 387 was enacted to prevent this. According to interviewees, the Resolution is openly flaunted and property dealers continue to act as brokers.

\section{HUMAN RESOURCES AND INSTITUTIONAL VULNERABILITIES}

There is a general lack of uniformity in how the 45 different Wasaeq procedures are applied. This lack of uniformity is, in and of itself, a significant vulnerability, as already lengthy and convoluted registration processes are further obfuscated by vague and inconsistently applied procedures. For illustrative purposes, Section 5 and 6 will focus primarily on the land registration process in Kabul.

\subsection{INTRA-INSTITUTIONAL ISSUES AND DELINEATION OF ROLES AND RESPONSIBILITIES}

Officials within the GDWR claim that organizational weaknesses are a significant obstacle to improved performance. According to the Wasaeq Regulation, the GDWR is obliged to apply effective modern management and maintenance principles, using modern technology, and observing international standards and practices. This is particularly important in the context of record keeping and database management.

Interviewees noted, however, that the Civil Division of the SC has taken over this responsibility, even though it has no legal basis for doing so. Aside from ignoring the Wasaeq Regulation, the SC is able to accomplish this because the GDWR is within the judiciary's organizational structure and has no dedicated budget and, therefore, no leverage or capacity to enforce its mandates. In addition, the SC's Makhzan Department, where Wasaeq-related record keeping is supposed to take place, does not cooperate with the GDWR.

The GDWR is seen as a relatively minor entity within the SC which, combined with its lack of dedicated budget and limited tashkil, is one of the reasons why it is frequently and easily circumvented. This is also facilitated by the fact that the GDWR has little, if any, presence at the provincial level. Because civil court judges are conducting much of the Wasaeq process at the provincial level, information sent from the provinces easily circumvents the GWDR and goes directly to the Makhzan Department in Kabul, creating a major conflict-of-interest issue.

\subsection{HuMAN RESOURCES}


To date, there are only four sections within the GDWR, each with three staff members. Persons familiar with the process stated that, given number of clients the GDWR deals with on a daily basis (700-1000), the minimum number of sections required in Kabul alone is eight. Interviewees commented repeatedly that it would be ideal for one section to be allocated for each of the 45 types of Wasaeq registration. But, as noted earlier, the GDWR also has minimal, if any, presence outside Kabul.

\section{PROCESS ISSUES}

To assess procedural vulnerabilities, the VCA Team focused on property and land registration in Kabul-a particularly lengthy process involving a wide range of actors. Through an examination of the land-registration process, as well as conversations with stakeholders about other Wasaeq procedures, the VCA Team found several vulnerabilities.

\subsection{Lengthy And Time-consuming Procedures}

Wasaeq procedures are complex, consisting of numerous discretionary transactions, every one of which provides a corruption opportunity for GDWR staff, court staff, and others. The land registration process, for example, consists of 30 different steps (See Annex 2). The lengthy and timeconsuming procedures compel many people to submit bribes to speed up the process. Respondents noted that many steps within various Wasaeq registration procedures could be easily consolidated, if not eliminated entirely.

\subsection{REPETITIVE ACTIVITIES}

Respondents also stated that most Wasaeq processes consist of unnecessarily repetitive steps. For example, land-registration applicants must obtain property value assessments for tax purposes from two different entities, neither of which applies clear or consistent standards. Moreover, even after assessment values have been determined by the relevant entities, GDWR staff or judges frequently refuse to accept the documentation for purposes of obtaining bribes. Manipulation of standards of proof or refusing to acknowledge that applicants have followed proper procedures is a common tactic used to obtain bribes.

\subsection{POSSIBILITY FOR DECEPTION AND FORGING}

One common theme that emerged was the fact that Wasaeq documentation is easily forged. This problem is basically rooted in lack of proper equipment, including printers and stamps. Poor information-management systems, as well as the divergent information streams used by the GDWR and the court system, increase the level of vulnerability posed by forgery issues. According to multiple interviewees, it is possible to bribe judges to accept even the most obvious forgeries.

\subsection{LACK OF AWARENESS ABOUT THE PROCESS}

Most clients seeking to obtain Wasaeq documents do not know, or are confused about, the steps needed for registering their documents. There appears to be a significant lack of clear, publicly available information on what the procedures are and how much they cost. This lack of clarity is 
easily exploited by corrupt actors and continues to provide a market for brokers or facilitators, many of whom are believed to be working in collusion with government entities involved in the process.

\subsection{DATABASE AND MAKHZAN DEPARTMENT ISSUES}

The VCA Team found that, while significant amounts of money were invested in the GDWR database, it does not serve as a comprehensive repository for Wasaeq records. The GDWR claims that they are not allowed access to the database and interviewees noted that only about 50\% of certifications conducted by civil court judges at the provincial level are entered into the database. Effectively, half of the Wasaeq documents being issued are not subjected to anything approaching modern information-management standards. The parallel structures also undermine accountability and oversight of the Wasaeq process. Among other things, this increases vulnerability to forgery and other types of fraud.

GDWR staff expressed concerns over database management, including the lack of any coordination mechanism between the GDWR and the courts. As appears to be a common theme, the GDWR actually has a mandate to manage the database, but this mandate is virtually ignored by the SC. Respondents attribute database management issues to a lack of cohesiveness and continuity in donorfunded programs designed to build capacity for database management and data entry. It was noted that this is one of the primary reasons why upwards of 80,000 Wasaeq records were erroneously erased from the database during a transition from one capacity building/database management program to another. Finally, respondents stated that, aside from the virtual alienation of the GDWR from database oversight and capacity-building problems, the Makhzan Department's leadership has been relatively disengaged from efforts to improve database management.

\section{CONCLUSION}

Given the number of different certifications issued by the Wasaeq Department, as well as the unique procedures associated with each, it is impractical to identify vulnerabilities and possible solutions for all of them. The VCA Team found at least 20 vulnerabilities in the land registration process alone. Several broad themes, however, are of particular concern.

First, while the GDWR has specific mandates and responsibilities, they are easily ignored or subverted by other departments within the SC. Laws and regulations are ignored and parallel structures have been established, undermining the effectiveness of the GDWR, as well as raising conflict-of-interest and accountability concerns. Put another way, if provincial courts are issuing Wasaeq certifications and sending them to the Makhzan Department, but not allowing GDWR staff to access the database, they are effectively issuing certifications without the ability for any stakeholders to scrutinize their processes.

Second, a related problem is the fact that the GDWR does not have its own budget or tashkil allotments consistent with the responsibilities legally allocated to it. This effectively prevents the GDWR from exercising its mandate and allows more powerful institutions to encroach upon its work.

Finally, respondents point to a combination of lengthy, confusing, and redundant procedures as creating an environment in which corruption thrives. The numerous discretionary transactions involved in Wasaeq registration all present corruption opportunities and, combined with the lack of 
public information, simply enhance the likelihood that bribes will have to be paid to obtain these essential services.

MEC has addressed land registration issues in previous recommendations, including the need for Arazi to take over that responsibility. Given that many of the problems identified by respondents and the VCA Team are due to the blatant undermining of mandates, rules, and regulations, MEC recommends that a comprehensive evaluation of the Wasaeq process be conducted to identify information-management weaknesses, establish accountability mechanisms, and reduce the number of discretionary transactions associated with Wasaeq registration.

\section{RESOURCES:}

- $\quad$ The Law on the Structure and Competencies of Courts (2013)

- The Regulation on Wasaeq Registration

- Bill of Costing Properties (Municipality)

- Presidential Decree on Establishment of Joint Pricing Commission

- Presidential Decree on Establishment of District Properties Pricing Committee

- Documents and Wasaeq Registration (Judge Atiqullah Raofi)

- $\quad$ Supreme Court High Consul Resolution Number 387, February 2011

- Wasaeq Guidelines (Decree 446, 1958)

- Report of the public inquiry into Land Usurpation by MEC

- Interviews and consultation meetings with different stakeholders 


\begin{tabular}{|c|c|c|}
\hline No & Vulnerabilities & Possible Solutions \\
\hline \multicolumn{3}{|c|}{ Legal/Regulatory Issues } \\
\hline 1 & $\begin{array}{l}\text { Paragraph } 1 \text { of Article } 74 \text { of the Law on } \\
\text { the Structure (Tashkil) and } \\
\text { Competencies of the Courts, in relation } \\
\text { to establishment of Wasaeq departments } \\
\text { within appeal court organizational } \\
\text { framework, caused dispersion of } \\
\text { responsibilities in organizational } \\
\text { structures and lack of coordination } \\
\text { between Wasaeq departments in the } \\
\text { country. }\end{array}$ & $\begin{array}{l}\text { After comprehensive review this article should } \\
\text { be amended according to the Wasaeq } \\
\text { regulation. }\end{array}$ \\
\hline 2 & $\begin{array}{l}\text { The Municipality Pricing Regulation is } \\
\text { not based on current market prices, } \\
\text { which is causing a loss of government } \\
\text { revenue. }\end{array}$ & $\begin{array}{l}\text { The Municipality Pricing Regulation must be } \\
\text { updated to ensure that assessments are based } \\
\text { on market prices. }\end{array}$ \\
\hline 3 & $\begin{array}{l}\text { Lack of oversight on implementation of } \\
\text { Supreme Court Council resolutions } \\
\text { causes the Wasaeq mandate to be } \\
\text { circumvented. }\end{array}$ & $\begin{array}{l}\text { Establishment of oversight mechanism for } \\
\text { Supreme Court Council resolutions. }\end{array}$ \\
\hline \multicolumn{3}{|c|}{ Organizational Structure } \\
\hline 4 & $\begin{array}{l}\text { Existence of Wasaeq Department within } \\
\text { appeal courts organizational structure } \\
\text { leads to parallel structures that } \\
\text { compromise information management } \\
\text { integrity and accountability. }\end{array}$ & $\begin{array}{l}\text { Tashkil should be reformed to establish } \\
\text { Wasaeq Departments at the provincial level. }\end{array}$ \\
\hline 5 & $\begin{array}{l}\text { Establishment of Joint Pricing } \\
\text { Commission violated the Municipality } \\
\text { Pricing Regulation and added redundant } \\
\text { steps to the registration process in } \\
\text { Kabul. }\end{array}$ & $\begin{array}{l}\text { The Joint Pricing Commission should be } \\
\text { removed, as it is illegal. }\end{array}$ \\
\hline 6 & $\begin{array}{l}\text { Limited human resources in Kabul } \\
\text { city/districts Wasaeq courts and daily } \\
\text { visit of } 700-1000 \text { applicants caused } \\
\text { improper processing of the documents } \\
\text { and lengthened the process. } \\
\end{array}$ & $\begin{array}{l}\text { Increased tashkils, dedicated budget, and re- } \\
\text { organization/re-allocation of responsibilities. }\end{array}$ \\
\hline 7 & Low capacity of staff causes delays. & $\begin{array}{l}\text { The capacity of the staff involved in the } \\
\text { process should be assessed and, in accordance } \\
\text { to their needs, trainings should be conducted. }\end{array}$ \\
\hline 8 & $\begin{array}{l}\text { Lack of coordination between involved } \\
\text { entities in the process caused lack of } \\
\text { timely information sharing and } \\
\text { overlapping of activities. }\end{array}$ & $\begin{array}{l}\text { The mechanism for sharing information } \\
\text { according to new electronic system should be } \\
\text { established and Wasaeq relevant departments } \\
\text { should have access to the system based on their } \\
\text { mandate. }\end{array}$ \\
\hline 9 & $\begin{array}{l}\text { Threats by officials and powerful } \\
\text { individuals can lead to extortion and } \\
\text { forged documents. }\end{array}$ & $\begin{array}{l}\text { Reduce the number of discretionary } \\
\text { transactions to minimize influence. }\end{array}$ \\
\hline
\end{tabular}




\begin{tabular}{|l|l|l|}
\hline 10 & $\begin{array}{l}\text { Filling in the application/request form } \\
\text { has become a black market activity and } \\
\text { has led to corruption, including possible } \\
\text { collusion between government staff and } \\
\text { facilitators. }\end{array}$ & $\begin{array}{l}\text { The Wasaeq Department should provide free } \\
\text { application forms and clear instructions for } \\
\text { completion. }\end{array}$ \\
\hline 11 & $\begin{array}{l}\text { Fees and tax payments made to } \\
\text { numerous entities unnecessarily } \\
\text { lengthens the process. }\end{array}$ & Single fee system needs to be developed. \\
\hline 12 & $\begin{array}{l}\text { Numerous, repetitive and redundant } \\
\text { steps increase discretionary transactions } \\
\text { for bribes. }\end{array}$ & $\begin{array}{l}\text { Processes should be analyzed and streamlined } \\
\text { to avoid unnecessary steps. }\end{array}$ \\
\hline 13 & $\begin{array}{l}\text { Lack of clarity and information on } \\
\text { processes/procedure confuses clients } \\
\text { and increases corruption vulnerabilities. }\end{array}$ & $\begin{array}{l}\text { Public information campaign should be } \\
\text { developed, including providing applicants with } \\
\text { pamphlets that explain procedures and fee } \\
\text { structures. }\end{array}$ \\
\hline 14 & $\begin{array}{l}\text { Poor printing quality and old/low } \\
\text { quality stamps }\end{array}$ & $\begin{array}{l}\text { Wasaeq certification should be printed and } \\
\text { stamped in a manner conducive to minimizing } \\
\text { forgery. }\end{array}$ \\
\hline
\end{tabular}

\section{Annex (2)}

Process Mapping for Wasaeq Registration (land/property registration)

\begin{tabular}{|c|c|c|c|}
\hline No & Steps/stages of the process & Responsible department & Time \\
\hline 1 & Preparation of application form & Applicants & One day \\
\hline 2 & Matching of application form with deed & \multirow{2}{*}{$\begin{array}{l}\text { Relevant Wasaeq } \\
\text { department }\end{array}$} & \multirow[t]{2}{*}{ One day } \\
\hline 3 & $\begin{array}{l}\text { Comparison of application form with prohibited list } \\
\text { (those places which are not permitted to be sold) }\end{array}$ & & \\
\hline 4 & $\begin{array}{l}\text { Sending the deed to archive department for } \\
\text { confirmation }\end{array}$ & & \\
\hline 5 & $\begin{array}{l}\text { Confirm the deed and sending of the deed to Wasaeq } \\
\text { related district }\end{array}$ & Archive & $\begin{array}{l}\text { One } \\
\text { week }\end{array}$ \\
\hline 6 & Distribution of processing form to applicants & $\begin{array}{l}\text { District Wasaeq } \\
\text { department }\end{array}$ & \multirow[t]{2}{*}{ One day } \\
\hline 7 & Visit the municipality district & Applicants & \\
\hline 8 & $\begin{array}{l}\text { Confirmation on comparison of property with the } \\
\text { prohibited list }\end{array}$ & \multirow[t]{2}{*}{$\begin{array}{l}\text { Relevant municipality } \\
\text { district }\end{array}$} & \multirow[t]{4}{*}{ 3-7 days } \\
\hline 9 & $\begin{array}{l}\text { Sending the Joint Pricing Commission to the field } \\
\text { and confirmation of property in the area }\end{array}$ & & \\
\hline 10 & $\begin{array}{l}\text { Confirmation on status of the area and estimation of } \\
\text { price according to the pricing bill }\end{array}$ & District Pricing Team & \\
\hline 11 & Clearance of municipality cleaning tax/charges & $\begin{array}{l}\text { Relevant municipality } \\
\text { district }\end{array}$ & \\
\hline 12 & $\begin{array}{l}\text { Visit of applicants to revenue department of related } \\
\text { district in order to clear his/her remaining tax. }\end{array}$ & Applicants & \multirow[t]{3}{*}{$2-5$ days } \\
\hline 13 & $\begin{array}{l}\text { Send the team to the field to check whether the } \\
\text { property is commercial or rental and estimate the } \\
\text { tax. }\end{array}$ & $\begin{array}{l}\text { Revenue department of } \\
\text { the district }\end{array}$ & \\
\hline 14 & Clearance of property tax. & $\begin{array}{l}\begin{array}{l}\text { Revenue department of } \\
\text { the district }\end{array} \\
\end{array}$ & \\
\hline
\end{tabular}




\begin{tabular}{|c|c|c|c|}
\hline 15 & $\begin{array}{l}\text { Visit the Joint Pricing Commission to control the } \\
\text { price. }\end{array}$ & Applicants & \multirow[t]{2}{*}{$1-3$ days } \\
\hline 16 & $\begin{array}{l}\text { Control the price by increasing the price in } \\
\text { contradiction to municipality price estimation bill. }\end{array}$ & $\begin{array}{l}\text { Joint Pricing } \\
\text { Commission }\end{array}$ & \\
\hline 17 & $\begin{array}{l}\text { Visit the municipality property confirmation } \\
\text { directorate. }\end{array}$ & Applicants & \multirow[t]{2}{*}{$1-2$ days } \\
\hline 18 & $\begin{array}{l}\text { Confirmation of the property based on property files } \\
\text { in municipality. }\end{array}$ & $\begin{array}{l}\text { Municipality properties } \\
\text { directorate }\end{array}$ & \\
\hline 19 & $\begin{array}{l}\text { Visit the revenue department of municipality to get } \\
1 \% \text { tax tariff of the transaction. }\end{array}$ & Applicants & \multirow[t]{2}{*}{ One day } \\
\hline 20 & $\begin{array}{l}\text { Distribution of } 1 \% \text { municipality tax tariff from } \\
\text { transaction of the property. }\end{array}$ & $\begin{array}{l}\text { Revenue department of } \\
\text { municipality }\end{array}$ & \\
\hline 21 & $\begin{array}{l}\text { Visit the relevant Wasaeq district to confirm 2-3\% } \\
\text { Wasaeq tax. }\end{array}$ & Applicants & \multirow[t]{2}{*}{ One day } \\
\hline 22 & $\begin{array}{l}\text { Distribution of 3\% tariff based on Joint Pricing } \\
\text { Commission estimated price. }\end{array}$ & $\begin{array}{l}\text { Relevant Wasaeq } \\
\text { department }\end{array}$ & \\
\hline 23 & $\begin{array}{l}\text { Visit the revenue department of the relevant district } \\
\text { to get } 1 \% \text { tax tariff to MoF. }\end{array}$ & Applicants & \multirow[t]{2}{*}{ One day } \\
\hline 24 & Distribution of $1 \%$ tariff of the property transaction. & $\begin{array}{l}\text { Relevant district revenue } \\
\text { department }\end{array}$ & \\
\hline 25 & Payment of tariff money in bank. & Applicants & One day \\
\hline 26 & $\begin{array}{l}\text { Submission of bank bill in district Wasaeq } \\
\text { department }\end{array}$ & Applicants & \multirow[t]{2}{*}{$1-2$ days } \\
\hline 27 & $\begin{array}{l}\text { Summoning both parties of the transaction and } \\
\text { obtaining their signatures. }\end{array}$ & $\begin{array}{l}\text { Relevant Wasaeq } \\
\text { department }\end{array}$ & \\
\hline 28 & Distribution of Wasaeq to clients. & $\begin{array}{l}\text { Relevant Wasaeq } \\
\text { department }\end{array}$ & One day \\
\hline 29 & $\begin{array}{l}\text { Registration of new deed in the relevant district and } \\
\text { property confirmation directorate of the } \\
\text { municipality. }\end{array}$ & $\begin{array}{l}\text { Relevant municipality } \\
\text { district and properties } \\
\text { directorate }\end{array}$ & $1-3$ days \\
\hline 30 & $\begin{array}{l}\text { Distribution of cleaning and power record books by } \\
\text { the name of new owner of the property. }\end{array}$ & $\begin{array}{l}\text { Relevant municipality } \\
\text { district }\end{array}$ & $1-3$ days \\
\hline
\end{tabular}

